\title{
RUA-ESCOLA: EXPERIÊNCIAS QUE PROVOCAM A FORMAÇÃO E A PRÁTICA DOCENTE PARA O MUNDO PÚBLICO
}

Lorena Lopes Pereira Bonomo ${ }^{\mathrm{i}}$

\begin{abstract}
Resumo: Defendendo que as práticas sociais são inerentemente espaciais e que essas constituem, ou deveriam constituir, ponto de partida e chegada das ações educativas, nesse artigo trago contribuições da geografia para pensar a condição espacial da rua e da escola, em seus aspectos educadores para a formação inicial e continuada de professores. Na perspectiva de inventar um currículo circunscrito na centralidade da experiência, apresento narrativas de espaços vividos pelas infâncias/juventudes e pela militância de professores, que destacam as dimensões éticas, investigativas, poéticas e políticas das pesquisas e das práticas docentes, especialmente na educação pública, e que atualizam as formas de ver o lugar-escola.
\end{abstract}

Palavras-chave: Educação; Geografia; Formação de professores; Experiência; Narrativa.

\section{STREET AND SCHOOL: EXPERIENCES THAT CAUSE TRAINING AND TEACHING PRACTICE FOR THE PUBLIC WORLD}

\begin{abstract}
Arguing that social practices are inherently spatial and that these are, or should be, starting and finishing point of the educational activities, in this article bring geography contributions to addressing the spatial condition of the street and school, in their educators aspects for the initial and continuing education teachers. In view of inventing a limited resume on the centrality of experience, present narrative spaces experienced by childhood / youth and the militant teachers who highlighting the ethical, investigative, poetic and political research and teaching practices, especially in public education, and to update the forms to see the place - school.
\end{abstract}

Keywords: Education; Geography; Teacher training; Experience; Narrative

Ainda vão me matar numa rua. Quando descobrirem, principalmente, que faço parte dessa gente que pensa que a rua é a parte principal da cidade.

(Leminski, 2013)

\section{De práticas sociais que sempre são espaciais: experiências de ruas narradas}

"Morador em situação de rua", "artista de rua", "essa criança daí vive (jogada) na rua", são costumeiras e naturalizadas as expressões que revelam a condição de precariedade, vulnerabilidade, perigo, vazio e desabrigo dos que tem ou insistem na rua como condição de 
suas existências. Nesse sentido, a rua se forja como lugar para não se estar, deseducadora, uma vez que estar exposto às suas impossibilidades não produz "nada que preste".

Compõe esse quadro contra a rua, sob um outro aspecto, porém complementar, a funcionalidade da rua transformada pela cidade capitalista. Se nossos espaçotempos cotidianos seguem objetificados, programados, cruzando velozmente as ruas e atribuindo múltiplos sentidos que desembocam no mesmo: passagem, circulação, privatização do público, espetáculo e normatização da vida, ganha corpo o que Lefebvre (1999) apresenta em seu debate contra a rua:

"Contra a rua. Lugar de encontro? Talvez, mas quais encontros? Superficiais. Na rua, caminha-se lado a lado, mas não se encontra. É o "se" que prevalece. A rua não permite a constituição de um grupo, de um "sujeito", mas se povoa de um amontoado de seres em busca. De quê? O mundo da mercadoria desenvolve-se na rua. A mercadoria que não pôde confinar-se nos lugares especializados, os mercados, invadiu a cidade inteira [...] A rua? Uma vitrina, um desfile entre as lojas. A mercadoria, tornada espetáculo ( provocante, atraente), transforma as pessoas em espetáculos umas para as outras. Nela, mais que noutros lugares, a troca e o valor de troca prevalecem sobre o uso, até reduzi-lo a um resíduo. De tal modo que a crítica da rua deve ir mais longe: a rua torna-se o lugar privilegiado de uma repressão, possibilitada pelo caráter real das relações que ali se constituem, ou seja, ao mesmo tempo débil e alienado-alienante. A passagem na rua, espaço de comunicação, é ao mesmo tempo obrigatória e reprimida. Em caso de ameaça, a primeira imposição do poder é a interdição à permanência e à reunião na rua. Se a rua pôde ter esse sentido, o encontro, ela o perdeu, e não pôde senão perdê-lo, convertendo-se numa redução indispensável na passagem solitária [...]". (LEFEBVRE, 1999, p. 30-31)

Porém, nessa denúncia mesma da crise de sociabilidade, o mesmo autor se propõe a realizar uma compreensão outra da rua, como elemento espacial que resiste, portanto, interferindo na discussão, pensando em movimento e por contradição. Assim também se coloca:

"A favor da rua. Não se trata simplesmente de um lugar de passagem e circulação. [...]. A rua? É o lugar ( topia ) do encontro, sem o qual não existem outros encontros possíveis nos lugares determinados ( cafés, teatros, salas diversas ). Esses lugares privilegiados animam a rua e são favorecidos por sua animação, ou então não existem. $\mathrm{Na}$ rua, teatro espontâneo, torno-me espetáculo e espectador, às vezes ator. Nela efetua-se o movimento, a mistura, sem os quais não há vida urbana, mas separação, segregação estipulada e imobilizada. Quando se suprimiu a rua ( desde Lê Corbusier, nos "novos conjuntos" ), viu-se as consequências: a extinção da vida, a redução da "cidade" a dormitório, a aberrante funcionalização da existência. A rua contém as funções negligenciadas por Lê Corbusier: a função informativa, a função simbólica, a função lúdica. Nela joga-se, nela aprende-se. A rua é a 
desordem? Certamente. Todos os elementos da vida urbana, noutra parte congelados numa ordem imóvel e redundante, liberam-se e afluem às ruas e por elas em direção aos centros; aí se encontram, arrancados de seus lugares fixos. Essa desordem vive. Informa. Surpreende. [...]. Na rua, e por esse espaço, um grupo (a própria cidade) se manifesta, aparece, apropria-se dos lugares, realiza um tempo-espaço apropriado. Uma tal apropriação mostra que o uso e o valor de uso podem dominar a troca e o valor de troca. Quanto ao acontecimento revolucionário, ele geralmente ocorre na rua. Isso não mostra também que sua desordem engendra uma outra ordem? O espaço urbano da rua não é o lugar da palavra, o lugar da troca pelas palavras e signos, assim como pelas coisas? Não é o lugar privilegiado no qual se escreve a palavra? Onde ela pôde tornar-se "selvagem" e inscrever-se nos muros, escapando das prescrições e instituições? " (LEFEBVRE, 1999, p. 29-30)

É essa leitura dialética da rua que nos toma nessa reflexão, mas insistindo na compreensão a contrapelo - para além de contrário ou revés, mas como ressignificação - dessa lógica a partir do consumo, ou seja, como apropriação, como evento. Sua potência em "tornar público" nos inspira a ensaiar aqui a provocação pela possibilidade da rua como uma abertura para a experiência. Como uma espacialidade educadora, pois ainda é digna de ser narrada e, ao se realizar, produz humanidade no homem.

Evidencia-se, portanto, que investimos aqui não na verificação, tão pouco na representação, mas na narrativa como instrumento educativo, na chamada à escuta. Se tratamos, como na perspectiva dessa revista, do ato de educar como arte, aposto, benjaminianamente, nas narrativas de espaços como meio, como método e no intercambiar da experiência como conteúdo, como corpo.

A narrativa nasce do encontro narrador-experiência, envolve quem conta e quem escuta, que atento retira lições, compartilha. Nossa capacidade de ouvir, de encontrar, parece não resistir aos nossos tempos acelerados e aos espaços percorridos, empobrecendo nossas experiências e causando a morte das narrativas. Justo por isso, tudo o que contraria e suspende essa lógica, ao emergir como proposta teórico-metodológica, que sempre é também política, pode ressignificar a formação e as práticas docentes.

Experiência como possibilidade de uma tradição compartilhada por uma comunidade humana, cuja raiz da palavra nos remete a fronteira e ao perigo. Assim, apontamos que o sujeito da experiência é aquele que atravessa, arrisca, rompe e narra. Nesse sentido, a articulação entre narrativa e experiência é realizada no espaço/tempo e nos leva a pensar em outro conceito: memória. Revisitar os lugares e o passado se constitui numa política de memória que, atualizada 
pelos imperativos do presente, produz geografias/histórias que serão narradas como experiências.

Visando a produções de saberes pelas práticas e pelas pesquisas com os cotidianos escolares, pelo viés do fora/ da rua, portanto colocando a "geografia na própria intimidade das nossas condições de existência" (MOREIRA, 2010, p. 45), escrevi uma tese de doutorado intitulada "Políticas e poéticas infantis na invenção de lugares-comuns". Esse convite de reflexão se constrói a partir da rememoração e de três narrativas (textos e imagens) do espaço da rua a partir de experiências docentes, investigadas no trabalho.

As práticas espaciais narradas mobilizam a constelação de conceitos geográficos, o que justifica o arranjo que agora apresento. Uma rua que se mostra lugar quando as questões de identidade/subjetividade e afetividade são levantadas. Uma rua que se apresenta como paisagem, já que seus aspectos de observação e leitura das formas se destacam. Uma rua feita território quando os modos de apropriação e as relações de poder se espraiam na narrativa.

Por fim, e a partir das lições que tiramos das experiências narradas da rua, das práticas sociais/espaciais e seus efeitos, retornamos nosso olhar para a escola e a questionamos: o que pode a escola como lugar-comum, visando a vida no mundo público?

\section{Rua-lugar}

A primeira narrativa-imagem que apresento acontece quando, numa atividade com alunos do ensino fundamental, oriento uma busca por imagens que se mostrem como evidências das felicidades possíveis na escola.

Resolvo participar de um projeto que pretende tratar de curtas-metragens nas escolas públicas. A dinâmica é a de escolher um dos filmes oferecidos na internet e desenvolver com as crianças atividades relativas ao conteúdo do filme. Encanto-me por "Pequenos tormentos da vida",ii um curta do tipo documentário, que se baseia no seguinte poema.

De cada lado da sala de aula, pelas janelas altas, o azul convida os meninos, as nuvens desenrolam-se, lentas, como quem vai inventando preguiçosamente uma história sem fim.... Sem fim é a aula: e nada acontece, nada... Bocejos e moscas. Se ao menos, pensa Lili, se ao menos um avião entrasse por uma janela e saísse pela outra! (QUINTANA, 2005, p. 30) 
O enredo desenvolve-se através das respostas de crianças do $4^{\circ}$ ano para a questão de quais seriam pequenos, médios e grandes tormentos da vida escolar. Uma sucessão de respostas-provocações, seguidas de brincadeiras, encaminham a narrativa fílmica. Ao trazer a ideia para os estudantes numa aula de geografia, alguém diz: chega de pensar em tormento, e olha que tem muitos! Escola também tem pequenas felicidades! A fala é rebatida com gritos de apoio, deboches, vaias e tudo o mais. Outra criança diz que leu algo sobre isso na apostila de língua portuguesa. E é a vez do fragmento de uma crônica de Cecília Meireles invadir a aula:

Mas quando falo dessas pequenas felicidades certas, que estão diante de cada janela, uns dizem que essas coisas não existem diante das minhas janelas, e outros, finalmente, que é preciso aprender a olhar, para poder vê-las assim. (MEIRELES, 2005)

Ninguém contesta mais, ao menos cessam os gritos revoltados com a possibilidade de existir felicidade na escola.

As imagens/ que remetem às brincadeiras, conversas, bagunças, que resistem às tentativas de disciplinarização na escola, dividem espaços com outras que trazem em seu bojo, a representação da conformação. O acerto, a nota, a meta do IDEB sendo batida, também povoam o discurso das crianças que deviam mostrar onde reside a felicidade na escola. Essa imagem foi selecionada para as pretensões deste texto:

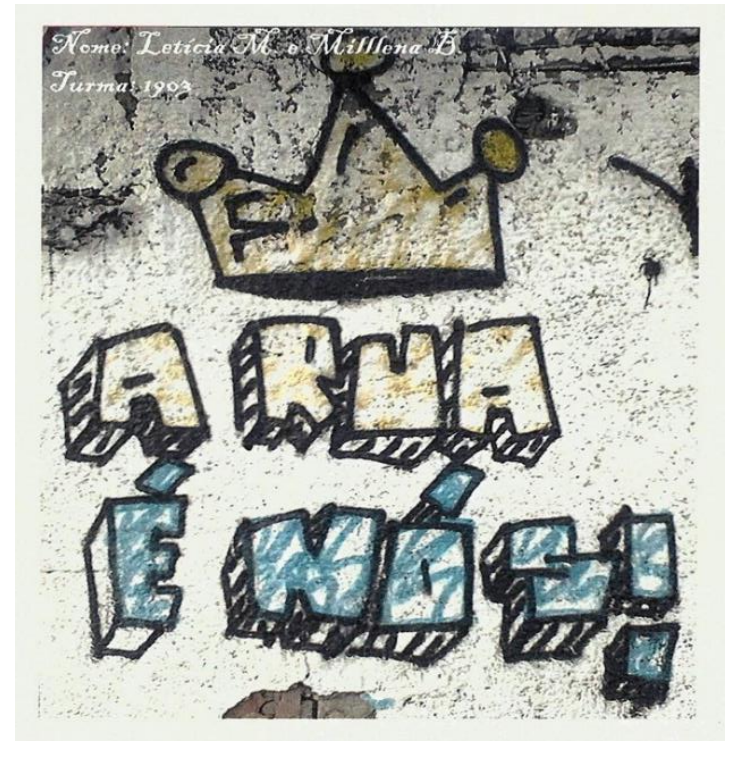

Imagem 1: Muro da escola. Acervo da autora 
Não nos interessa aqui explicar o que as crianças pensaram ao produzir essa imagem quando provocadas, mas conversar a respeito de seus efeitos. O que ter essa frase, e toda sua simbologia, registrada nos muros escolares nos oferece a pensar? A rua é nós! Como nos ensina Benjamin (1994), o narrador é antes de tudo um conselheiro, nos dá lições. Ao refletir com essa imagem extraio duas.

A primeira se refere às subjetividades que irrompem com o modo instituído de ser, estar e fazer. Vedar o espaço da rua é um conselho comum, como estratégia, mecanismo visando o controle da criança-problema para a escola. Muitos estudantes das classes populares, de forma mais complexa do que já foi exposto, tem na rua, mais ainda que em casa, o seu lugar. Rua que se constitui lugar de aprendizagem, tensão, negociação. Para além das explicações objetivas quanto a escassez de áreas destinadas ao lazer, fuga das obrigações desde cedo instituídas, como as tarefas domésticas ou cuidado dos menores, a rua parece permitir ser, por vezes mais até que a própria casa. Rompem com a lógica hegemônica de que o estranho, o de fora, o longe é perigoso e enxergam na rua, características do que poderia ser o mundo da casa. Não são estrangeiros na rua, como podem parecer na escola. A estética, a provocação, do dizer-se rua na escola. De afirmar que a instituição moderna que tem entre seus propagados atributos a retirada da rua-mundo, não se realiza. Oferecendo uma hospitalidade radical, sem perguntas, sem tematizar o sujeito já que não é seu lugar nem dela se apropria, se constitui numa relação ética com as infâncias/juventudes. Ser rua como dizer-se no mundo, criando subjetividades rebeldes (SANTOS, 2007) pelo improviso, pelo descontrolado e pelo reinado da liberdade.

A segunda lição se refere à dimensão do lugar público. Na imagem, a rua é primeira pessoa do plural: nós. Ao chegar aos estudantes, pelo viés da geograficidade, vi emergir a ideia da rua como lugar-comum. Se o espaço é, para nós da geografia, o quadro que dá sentido, uma vez que se configura simultaneamente como substrato das práticas sociais e condição de sua existência, o lugar é o espaço sensível, de um cotidiano compartilhado e assim localização da coexistência e do conflito, já que todo lugar é, a seu modo, o mundo (SANTOS, 2006). É Massey (2008) que nos aponta que:

O lugar, em outras palavras - como muitos argumentam -, nos modifica não através de um pertencimento visceral, mas através da prática do lugar, da negociação de trajetórias que se intersectam, lugar como arena onde a negociação nos é imposta. (MASSEY, 2008, p. 111) 
Penso que aqui, a autora e a imagem recolocam uma questão para a formação de professores, pensados como aqueles que já nascem compostos, e tem no outro o seu transbordamento, o que a rua nos ensina? Podemos falar hoje que a escola é nós? A rua como lugar provoca a dimensão ética da docência.

\section{Rua-paisagem}

A segunda narrativa se constrói a partir das imagens que estudantes produziram para a proposta de registrarem as paisagens suburbanas (a escola onde a pesquisa se realizou se localiza no bairro de Marechal Hermes, subúrbio carioca). A paisagem como o apreensível do espaço pelo sentido da visão, numa possibilidade de "exprimir as sucessivas heranças das relações entre homem-natureza" (SANTOS, 1996, p. 83), mas sempre muito marcada pela descrição, aparece na coleção dos estudantes?

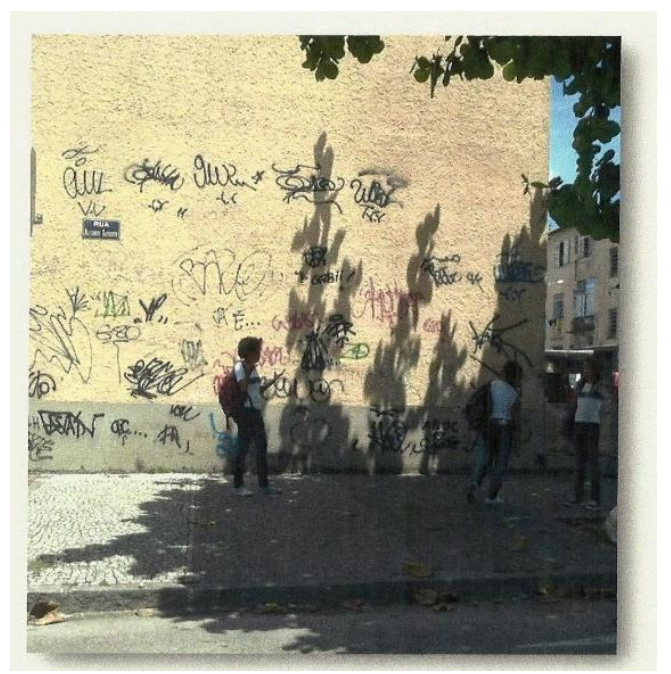

Imagem 2: Alunas, prédios na praça em frente à escola e sombra da árvore. Acervo da autora. 


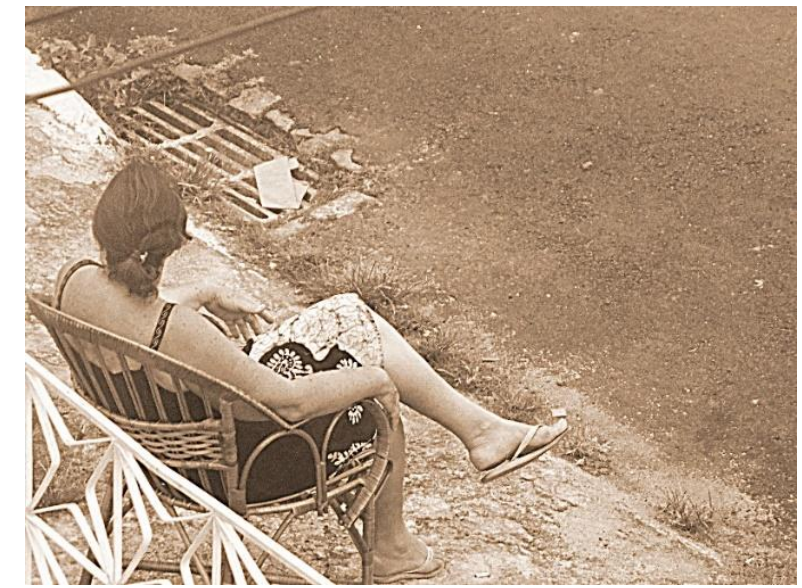

Imagem 3: Senhora sentada na calçada. Acervo da autora.

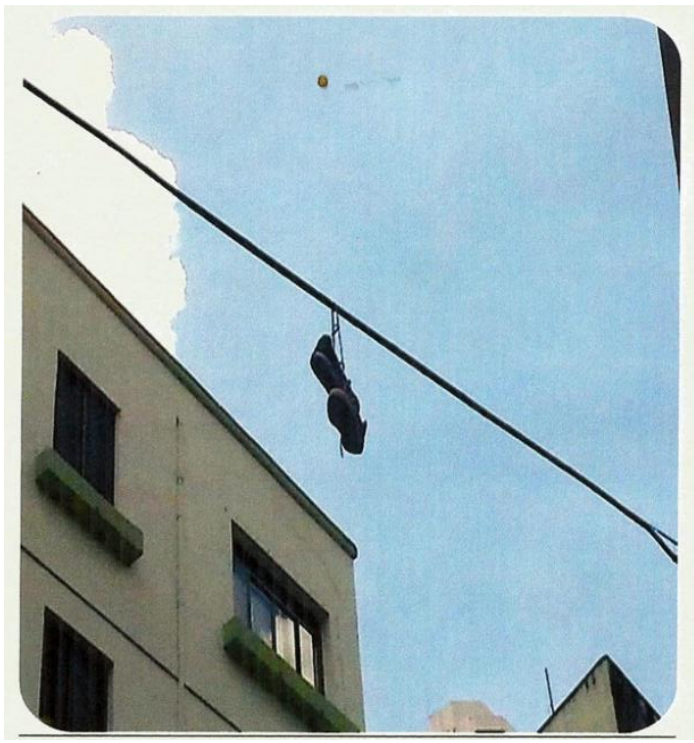

Imagem 4: Tênis no fio. Acervo da autora.

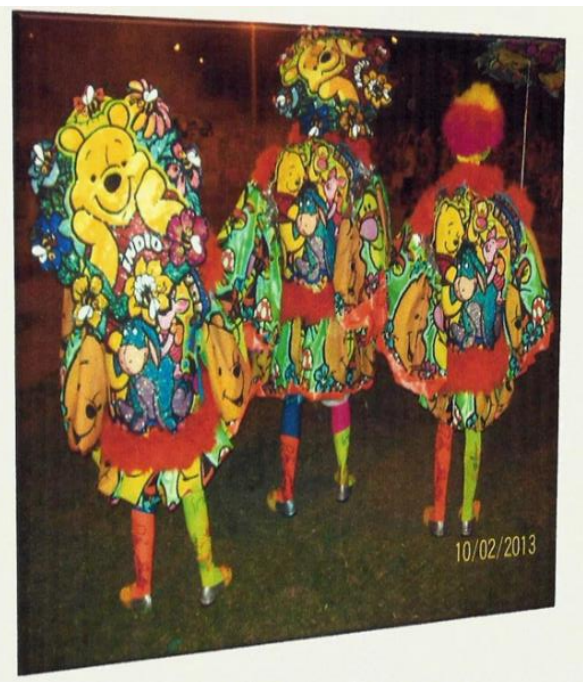

Imagem 5: Grupo de bate-bolas. Acervo da autora. 


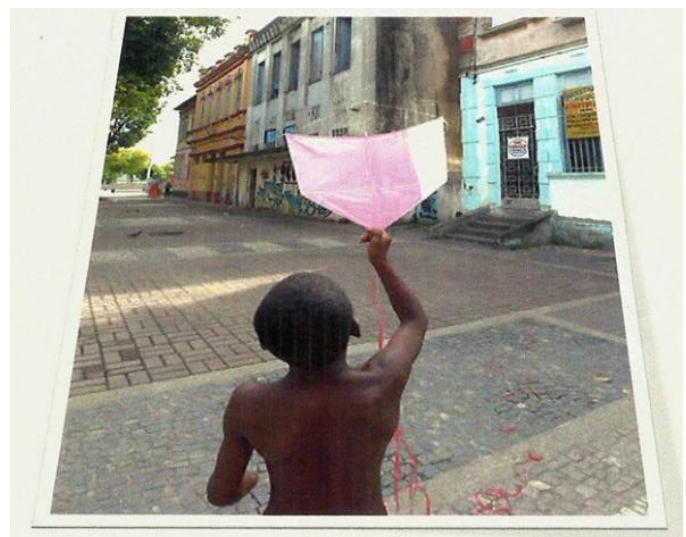

Imagem 6: Menino e pipa. Acervo da autora.

Ao derramarem a geografia vivida nas ruas suburbanas a partir dessas imagens, as crianças narram, não se limitam a descrever, seu pedaço na cidade expressos na paisagem da rua: pelo jogo, pelo uso, pela cultura, pelo ritmo, pela inventividade, pela transgressão. As paisagens narradas assumem suas formas pelas vidas que as anima (SANTOS, 1996, p. 103), encontradas na experiência. E também essa rua que se mostra paisagem nos provoca quanto ao olhar investigativo.

Walter Benjamin (1989) nos apresenta, em seus ensaios sobre a obra de Baudelaire, a figura do flanêur, que perambula pelas cidades e suas ruas banalizando o espaço e, por isso, livre no prazeroso exercício de observar.

A rua se torna moradia para o flanêur, que, entre as fachadas dos prédios, sente-se em casa tanto quanto o burguês entre suas quatro paredes. Para ele, os letreiros esmaltados e brilhantes das firmas são um adorno de parede tão bom ou melhor que a pintura a óleo no salão do burguês; muros são a escrivaninha onde apoia o bloco de apontamentos; bancas de jornais são suas bibliotecas, e os terraços dos cafés, as sacadas de onde, após o trabalho, observa o ambiente. Que a vida, em toda a sua diversidade, em toda a sua inesgotável riqueza de variações, só se desenvolva entre os paralelepípedos cinzentos e ante o cinzento pano de fundo do despotismo: eis o pensamento político secreto da escritura de que faziam parte as fisiologias (BENJAMIN, 1989, p. 35).

As fantásticas imagens reveladas pelos estudantes, ao serem instigados a pensar as marcas de uma geografia suburbana, evidenciam um viver a cidade como flanar que resiste. Aliás, o mesmo autor já diria que "A rua conduz o flanêur em direção a um tempo que desapareceu [...]. Entretanto, este permanece sempre o tempo de uma infância” (BENJAMIN, 
2006, p. 242). Exibem-se como uma infância-cronista da cidade, posicionada, pelo lúdico, no contra fluxo ao modelo capitalista que dita um tempo que só corre e um espaço que só se esvazia.

Mas não há o que se enganar. Não foram levadas a flanar a partir de uma estratégia pedagógica. Convidaram-me. Mostraram suas composições enquanto flanêurs (e em sua dialética: de um lado, olhado por tudo e por todos, como um verdadeiro suspeito e, de outro, como o homem que dificilmente será encontrado, o escondido (Ibid., p. 265).

Ao testemunhar o outro e o entorno, testemunharam a si mesmos e ensinaram a professora. Freire (1996) nos ensina que ensinar exige pesquisa, já que não há docência sem discência (p.21). Se a pergunta, o movimento de busca, a constatação e ou a contestação, são inerentes à natureza docente, o movimento "da curiosidade ingênua à curiosidade epistemológica” (FREIRE, 1996, pág. 31) se traduz como fio condutor da sua prática, tanto para a sua própria formação contínua na docência quanto ao seu processo com os estudantes. Ao misturar os espaços rua-escola, acionando suas especificidades e possibilidades, também se rompem outras fronteiras, como a que estabeleceria onde se aprende e onde se ensina. A infância-flanêur na rua-escola, desvela e atualiza o que em si foi naturalizado. Deixar de ensinar o já sabido para ensinar diferente exige deixar de pensar como se pensava.

Uma certa poética do espaço e do magistério também transborda. Ao capturar as paisagens nas ruas suburbanas, os estudantes imaginam espaços não como pontos na superfície, como sugerem os mapas, mas como reunião de multiplicidades de trajetórias, gerando maneiras outras de pensar e agir, de geografar, de seguir produzindo mapas de desejos. São bonitas e nos humanizam, as imagens-pensantes das geografias suburbanas. Nos oferecem um dar-a-ver, nos apontam nossas cegueiras. Resistir a uma docência e sua respectiva formação como puro treinamento técnico, também impele resistir a um modelo que segue reduzindo e objetificando nossas relações a números, metas, desempenhos, esvaziando de sentido nosso fazer, enquanto instrumentaliza ideologicamente (embora negue e mascare de técnica) nosso saber. A rua como paisagem provoca a dimensão poética-investigativa da docência. 
Rua-território

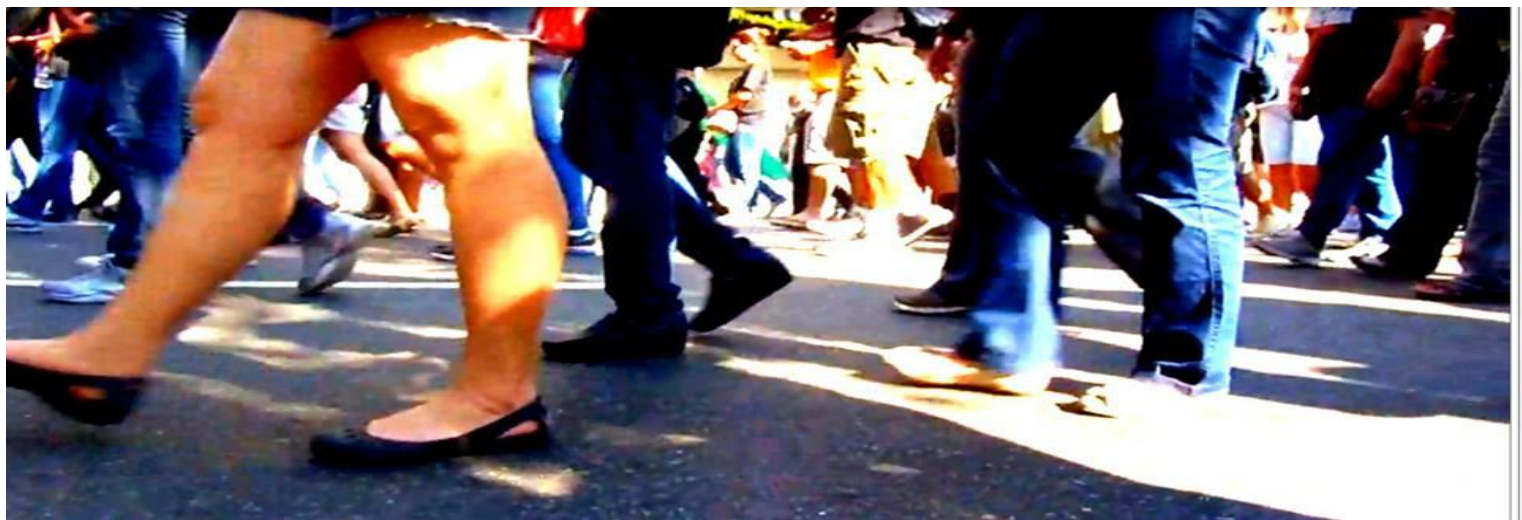

Imagem 7: passeata de professores na greve da Rede Municipal do Rio de Janeiro em 2013. Acervo da autora.

De pés livres, mãos dadas e olhos atentos, como diria Guimarães Rosa, a cidade tem nos visto passeatar. Multidões olham e são vistas. Alguém em alto som convoca e de braços levantados decidem resistir. Passos firmes, femininos em grande parte, interrompem, incomodam, ou ainda, desacomodam e parecem querer marcar-me para dizer, de outros modos, que em mim também é seu lugar. Fazem os carros parar, para também vê-los passar, inventamse corpos-fluxos. Me invadem com seus cantos, seus choros, seus abraços e seus risos. Levantam palavras ao céu e se comportam como tão donos delas quanto de mim. Eu-rua me inscrevo na escrita docente. Eu-professor me inscrevo e reinvento no espaço público. Chamam e as janelas parecem responder ritmando o piscar de luzes e acenando panos pretos, verdes, amarelos, alguém dança, outros tantos aplaudem. No jardim as flores são colhidas, e do mesmo modo que papéis picados e bolinhas de sabão, chovem em mim, misturadas as lágrimas de quem me passeia. Daqui onde sou Av. Presidente Vargas, Zumbi os vê passear, da estátua-multidãoem movimento, percebo orgulho ao intuírem a quizomba como constituição

Eis que me atravessam onde situo escola. As crianças correm, apertam mãos e rostos nas grades que as separam de quem sempre esteve lá dentro. Sorriem de fora, sorriem de dentro, panelas batidas de cá, aplausos de lá. Abaixa o rosto envergonhado alguém que parece duvidar do lado que está. Marcha segue, não cansam de se juntar.

Nunca tantos nas sacadas viraram ao mesmo tempo seus olhos-máquinas para mim. Inventam suas maneiras de fazer-me rua, aqui onde batizaram-me Rio Branco. Tomam minha forma-praça do povo, Cinelândia. Ocupam minha forma-câmara, montam barracas e aqui, nesta casa, dormem. Os de dentro são alimentados e animados pelos de fora, desconhecidos até então 
e agora amigos de causa rua-escola. Ao se apropriarem de mim de tantas formas, criam novas maneiras de eu-território.

E é 27 de setembro. [Tempo de fazer da rua, mais que sempre, território de infância. Juntar-me com outras crianças, mochilas nas costas e pegar doce. Levar sempre os menores, declarar ter sempre 12 anos no máximo, ter irmãos que não puderam ir e conseguir assim pegar um saquinho a mais, correr a cada carro que para, disputar nas filas os convites que as casas mais generosas já distribuíam, contar os saquinhos, trocar os doces, encher as bacias. Saborear suspiros, cocadas, bananadas, chocolates, lembrando das aventuras pelo bairro, ocupadas pela nossa festa, da vontade coletiva de crianceirar na rua].

Alguém entrega suprimentos para os que resistem na trincheira de luta, a menina professora segura um saquinho de papel que alguém entrega. Pelo tato descobre o que é e segura o tempo. Sorri e passa ao amigo, que coloca na bolsa improvisada que sobe puxada pela corda jogada da janela do banheiro da câmara, limiar que se inventa. Sabendo que ali vão doces para os adultos que já correram naquelas ruas como crianças, pensa: vinte e setes de setembro sempre se encontram, no agora, e sempre no mesmo espaço, aqui. Eu-rua-mundo sorrio também. (BONOMO, 2015).

$$
* * * * *
$$

A costura entre memória e geografia se dá pela narrativa. Ao rememorar, para além de fazer o movimento de repetir o que se lembra, abre-se ao esquecido, ao recalcado. Definida como uma atenção precisa ao presente, rememorar não se trata assim apenas do não esquecimento do passado, mas de acioná-lo na atuação sobre o agora. Traz assim uma ampliação da noção de testemunha, não só aquele que vê, mas como o que não vai embora, que ouvindo a narração a leva adiante, por assim entender que essa repetição é criadora, é o que torna possível uma reinvenção do presente. Com Benjamin (1994) aprendemos que a cada época é preciso arrancar à tradição ao conformismo, que quer apoderar-se dela. Mais do que "o que foi" cada história é vista como um "a fazer", uma ação possível. Mais do que "palco das ações" cada espaço se mostra interação, uma ação transformadora.

Escrevi essa narrativa a partir das manifestações e atos da greve de professores em 2013 na Rede Municipal do Rio de Janeiro. Quando, depois de 19 anos, grande parte da categoria tomou as ruas cariocas inúmeras vezes para denunciar a precarização do trabalho docente, num contexto de desvalorização profissional com a inexistência de planos de carreira, baixos salários 
e dificílimas condições de trabalho. Tudo isso somado a uma política educacional completamente voltada aos interesses do grande capital, com enorme interferência teóricometodológica, na produção de um currículo não dialogado com a ampla maioria dos professores. Dessa narrativa emerge outra rua vivida na educação, e que interfere diretamente na formação do educador.

A luta é educadora. A compreensão de que toda ação pedagógica é política emerge da narrativa. Parece óbvio, mas não é. Com o fortalecimento das concepções de que a educação é sobretudo uma mercadoria e em tempos onde projetos como o "Escola sem partido", confundem, inclusive pela linguagem/discurso, nossas ações, é preciso reiterar o que Freire (1996) nos lembra em sua pedagogia para a autonomia: Ensinar exige reconhecer que a educação é ideológica (p.125). Portanto, a neutralidade é impossível pois em si já é escolha. Ao não formar (e, portanto, não se formar) para a adequação, a conformação mas para a transformação do que aí está, e preciso a reiteração de que a mudança sempre é processo político, portanto só se concretiza por posicionamento.

Essa criticidade, vista como (re) construção profissional inerente à docência, forma o que Gallo (2002) denomina professor-profeta, como "alguém que vislumbrando a possibilidade de um novo mundo faz a crítica do presente e procura apresentar, então, a partir da crítica do presente, a possibilidade de um mundo novo”. (GALLO, 2002, p. 170). Mas a sua realização na rua territorializada pela causa da educação pública, na luta coletiva pelos direitos dos trabalhadores-professores, sendo possível reconhecer a profissão dentro da totalidade social e lê-la politicamente (SOUZA NETO, 2005), forja-se como espacialidade formadora do que se reconhece professor-militante, aquele que é

Sempre uma construção coletiva. Talvez o profeta seja mais aquele que anuncia do ponto de vista individual. Mas o militante tem sempre uma ação coletiva; a ação do militante nunca é uma ação isolada. Então, o professor militante seria aquele que, vivendo as misérias dos alunos ou as misérias da situação social da qual ele participa procuraria, coletivamente, ser um vetor da produção de superação, de condições de superação dessa miséria, ser um vetor de libertação, de possibilidades de libertação. (GALLO, 2002, p. 175).

A rua como território provoca a dimensão política da docência.

\section{Escola-rua: As práticas sociais - espaciais como ponto de partida e chegada}


Ao tratar de levantar questões para o currículo e formação docente através das espacialidades, corroboro com Porto-Gonçalves (2002) e reforço que há várias maneiras possíveis de se ler/sentir/pensar/GRAFAR os espaços, de exercitar geo-grafias. É essa ordinariedade, essa interação produtiva, que podemos delegar ao espaço, inventado pelas infâncias/juventudes, pela experiência militante, pelos flanêurs, nos encontros mundo-rua que narramos até aqui.

A rua praticada como encontro, a partir de aulas que assim também se pretenderam, se inscreveu numa perspectiva de prática menor conectada às ideias de Deleuze e Guatarri (1977), afinal:

\begin{abstract}
"Menor" é aquela prática que assume sua marginalidade em relação aos papéis representativos e ideológicos da língua e que aceita o exílio no interior das práticas discursivas majoritárias, formulando-se como estrangeiro na própria língua, gaguejando e deixando emergir o sotaque e o estranhamento de quem fala fora do lugar ou de quem aceita e assume o não-lugar como seu deserto, na impossibilidade de uma origem. Assim, o escritor ou o artista não precisa efetivamente formar parte de uma minoria, basta "encontrar seu próprio ponto de subdesenvolvimento, seu próprio patoá, seu próprio terceiro mundo, seu próprio deserto. (DELEUZE e GUATTARI, 1977, p. 28-29)
\end{abstract}

Os processos educativos que vimos narrando até aqui, e continuamos, vem se mostrando muito mais à vontade nessa perspectiva. A educação maior não nos ajuda a compreender essas outras temporalidades e espacialidades que se forjam nas coletividades, nas desterritorializações e nas aulas que acontecem, pois se ocupa do controle, das análises, das conformações, das instrumentalizações a serviço dos aparelhamentos.

Optamos por refletir o efêmero cotidiano, as geografias mínimas, numa educação menor que não elimina a vida e seus espaços de acontecimento, não elimina a potência do encontro. Portanto se somam como espaços para compartilhar, pensar e atuar no mundo, e defendem a esfera pública.

As narrativas das experiências e a coleção de suas lições que (re)inventaram, e redimensionaram a rua, indagam nossa compreensão da condição pública da escola, e vemos nela se instalar o paradoxal compromisso docente. Cuidar de fazer durar o mundo, renovando sua herança pública. Porém, educando para o comum, entendendo que o comum só é possível na diferença (GALLO, 2014), que ciceroneia o novo. 
O mundo se inventa nesse nosso lugar-comum, em seu sentido público. E a busca pelo que vimos fazendo junto ao novo que chega na escola encontra eco, ao meu ver, nessa compreensão. Se concordamos com Arendt (2002) e pensamos a educação como o movimento de iniciar os novos num mundo comum e público por nossas heranças e tradições conservadas, então a escola pública, como instituição que se constrói sob essa insígnia, encontra sua razão, mas também sua crise.

No cerne da crise: permanecemos perdendo nosso senso-do-comum e essa dimensão da formação para o mundo público e seguimos tratando a educação escolar como investimento privado para ganhar a vida. Vida cada vez mais individual, e não singular, ganhar cada vez mais como competir: ganhar de, e não ganhar com. Os debates em defesa e contra a rua - na perspectiva lefebvrianas que abriram esse texto, tem argumentos muito coincidentes com os debates em defesa e contra a escola.

Provocados pelos sujeitos dessas experiências: o flanêur, as infâncias/juventudes, os professores-militantes, uma escola-rua pode ser desejada, aquela onde nos expomos a uma coisa em comum, de uso livre, e nos engajamos no pensamento público, como comum pois compartilhado. (MASSCHELEIN, 2013).

Resgatamos com o autor supracitado o sentido da palavra escola, a scholè, que se indica como tempo livre, não da reprodução da ordem social. A rua como escola, nas experiências narradas, resgata a scholè. Um estado não necessariamente institucional, mas de estudo, pensamento e exercício. Ou seja, um espaçotempo público onde as "respostas" foram produzidas, inventadas, dispostas, expostas, para nosso livre olhar e aprendizado juntos, se tornando comuns.

Jam Masschelein (2013) nos oferece ainda três palavras para entender o que seria a forma-escola nessa perspectiva, da recuperação de seu significado: suspensão, profanação e atenção. Suspensão como des-privatização, des-apropriação, como um livrar-se das amarras da produtividade. Profanação como desconexão de tempo, espaço e material de seu uso regular, lugar com espaço e tempo mundano, onde é possível livrar-se para conhecer por conhecer, pensar por pensar. Atenção quando um espaçotempo de interesse pelo mundo, por sujeito reais, e não como recursos, produtos.

Temos visto outro movimento. A redução do público da escola pública em referência apenas ao seu acesso, uma possibilidade de "todos". Envolta numa linguagem econômica, um 
pensamento produtivista e visando uma qualidade numérica. Discurso este que desavergonhadamente se propaga e estampa jornais de domingo.

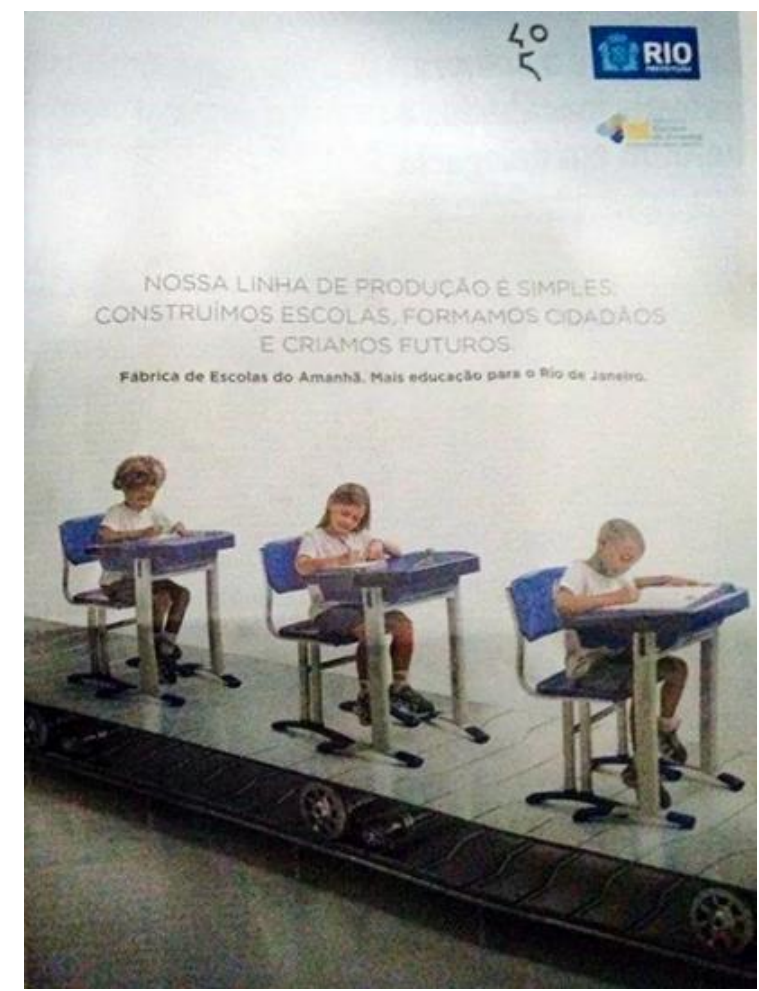

Imagem 8: Propaganda da "Fábrica de escolas" em jornais do Rio de Janeiro, em 2013.

Diz muito do discurso oficial também os enunciados "Nossa linha de produção é simples. Construímos escolas, formamos cidadãos e criamos futuros". Começando pela escolha dos termos fábricas/linha de produção correspondendo perfeitamente a lógica mercadológica a qual está submetido todo o sistema educacional carioca até ao prepotente determinismo que indica que a criação de espaços, quaisquer deles, corresponde ao uso que os sujeitos farão dele. Neste caso, o nós (pronome escondido no "construímos", "formamos" e "criamos") se refere a eles. Palavras-mortas.

Mas, se arrepia pensar o que vem chamado de cidadania, que futuros desejam criar, as narrativas de experiências até aqui ofereceram outras três palavras: ética, política e poética. Para mobilizar o que temos pensado e compreender a escola nessa perspectiva, ampliando seu entendimento público, pela esfera política e poética da coexistência, qualificada como lugarcomum. Experiências da escola-rua como alegria da potencialidade forjada nas fendas do discurso oficial. Nos sombrios tempos da educação maior, essas histórias e geografias vêm 
contar de uma educação menor, nos detalhes, nas frestas, nas cores da vida escondidas na nuvem da rotina desse espaço-escola que produzimos juntos.

\section{“Não há saídas, só ruas, viadutos e avenidas” (Régis Bonvicino)}

O mundo comum não está dado, surge no encontro geracional, onde as coisas do mundo são postas à disposição. A vida na rua, numa leitura espacial de suas práticas, e na escola, como scholè, engendrou outra política de espaçotempo nas narrativas sob as quais me dobrei. Espaços públicos onde a vida social é problematizada, dando visibilidade, reconhecendo, se reinventando.

Para além do modelo de instrumentalização técnica que insiste em atribuir aos professores o papel de agentes de preparação do futuro dos outros, necessariamente adaptados, flexíveis, adequados às exigências do mercado, pensar a contrapelo a rua, com sua aura mesma de vulnerabilidade, improviso, contestação, nos impele a compreender um currículo que se forja na vida. Formar-se na perspectiva de uma educação menor exige provocar as dimensões ética, poética, investigativa e política da docência. Trata-se de uma aposta nas brechas, nas fraturas do modelo, nas dobras dos discursos, nas táticas e astúcias quando praticamos a escola e a rua como lugares-comuns, voltadas ao mundo público.

Nós não somos, nós transitamos.

E seguimos deixando marcas nos lugares, sendo marcados por eles.

Marcas aqui não só como cercanias, definições, limitações, regulações.

Não só, e também.

O oleiro na argila de que fala Benjamin contra a cultura de vidro que não permite o rastro, tão pouco a aura.

Perante os rabiscos laváveis na camisa do uniforme no final de cada ano.

Ante o estudo como movimento de alimentar o sonho.

Durante o sorriso, do professor, do colega, das amizades.

Exceto a "boca escancarada cheia de dentes esperando a morte chegar", de

Raulzito.

Perante o desmonte, por dentro, do que conforma.

E pela rua, que é o fora inventado.

Para o que mancha e suja... que perigo pode ser a limpeza!

Mas pelo digno, não confunda!

Desde ontem, com o hoje e rememorando o amanhã.

Com os cotidianos, com as crianças, com os professores, com a escola. Mais com e menos sobre.

Até com a luta que muda a vida.

Exceto a que se arma para manter o sossego. 
Pela pergunta, pela pergunta, pela pergunta.

Tanto cabeça, quanto olho, quanto mão, quanto abraço

Muito ouvido!

Sobressaltos. Estranhamentos.

"Nada deve parecer natural".

Afora o estar juntos.

Diante do tempo que teima em sobrar, do espaço que seduz no ocupar

Todos sinais, do que é a escola

Todos sinais que desinvisibilizam o que pode e não pode ser a escola

Alerta do Pouco. Vontade do Muito.

Ou o contrário.

Desde um mundo que não é, segue sendo. (BONOMO, 2015, p. 165-166)

\section{Referências}

ARENDT, H. O que é política? Rio de Janeiro: Bertrand Brasil, 2002.

BENJAMIN, W. Charles Baudelaire, um lírico no auge do capitalismo (Obras escolhidas III). São Paulo: Brasiliense, 1989.

. Magia e técnica, arte e política (Obras escolhidas I). São Paulo: Brasiliense, 1994.

. Passagens. Belo Horizonte: Editora UFMG, 2006.

BONOMO, L. Políticas e poéticas infantis na invenção de lugares-comuns. 02 Fev. 2015. 176

f. Tese (Doutorado) - Universidade Federal Fluminense. Niterói. Mimeo.

DELEUZE, G.; GUATTARI, F. Kafka: por uma literatura menor. Rio de Janeiro: Imago, 1977.

FREIRE, P. Pedagogia da autonomia: saberes necessários à prática educativa. São Paulo: Paz e Terra, 1996.

GALLO, S. Em torno de uma educação menor. In: Educação \& Realidade. Gilles Deleuze. v. 27, n.2, jul/dez 2002. Disponível em:

http://seer.ufrgs.br/educacaoerealidade/article/view/25926. Acesso em 20/06/2016

. Mínimo múltiplo comum. In: RIBETTO, A. (Org.). Políticas, poéticas e práticas.

Rio de Janeiro: Lamparina, FAPERJ, 2014.

LEFEBVRE, H. A revolução urbana. Belo Horizonte: Editora UFMG, 1999.

LEMINSKI, P. Toda poesia - Paulo Leminski. São Paulo: Companhia das letras, 2013.

MASSEY, D. Pelo espaço: uma nova política da espacialidade. Rio de Janeiro: Bertrand do Brasil, 2008. 
MASSCHELEIN, J.; SIMONS, M. Em defesa da escola - uma questão pública. Belo Horizonte: Autêntica, 2013.

MEIRELES, C. A arte de ser feliz. 2005. Disponível em:

http://pensador.uol.com.br/frase/MjIzNTMw . Acesso em: 18/06/2016.

MOREIRA, R. O que é geografia. São Paulo: Brasiliense, 2010.

PORTO-GONÇALVES, C. W. Da geografia às geo-grafias: um mundo em busca de novas territorialidades. In: CECEÑA, A.; SADER, E. (Orgs). La guerra infinita: hegemonia y terror mundial. Buenos Aires: Clacso, 2002.

QUINTANA, M. Lili inventa o mundo. Rio de Janeiro: Global, 2005.

SANTOS, B. S. Renovar a teoria crítica e reinventar a emancipação social. São Paulo:

Boitempo, 2007.

SANTOS, M. A natureza do espaço. Técnica e tempo. Razão e emoção. São Paulo: Hucitec, 1996.

. Por uma outra globalização: do pensamento único à consciência universal. Rio de Janeiro: Record, 2006.

SOUZA NETO, M. O ofício, a oficina e a profissão: reflexões sobre o lugar social do professor. Cad. CEDES [online]. 2005, vol.25, n.66, pp.249-259. Disponível em: http://dx.doi.org/10.1590/S0101-32622005000200007. Acesso em: 15/05/2016.

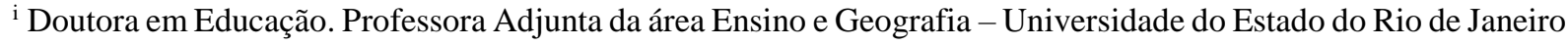
- Faculdade de Educação da Baixada Fluminense.

ii Pequenos Tormentos da Vida, Documentário, 2006, De: Gustavo Spolidoro.
} 